\title{
ASSESSMENT OF ALLELOPATHIC EFFECT OF CALOTROPIS PROCERA ON CHROOCOCCUS MINUTUS.
}

\author{
Vishwakarma, $\mathbf{S}^{1}$., Bhowal, $\mathbf{M}^{3}$., and Cherian, K. $\mathbf{J}^{\mathbf{2}}$. \\ 1, 3 Department of Botany, Hislop College, Nagpur, M.S., India \\ 2 Dept. of Botany, Sindhu Mahavidyalaya, Nagpur, M.S., India \\ Email: sharmasangeeta786@gmail.com
}

\begin{abstract}
:
In allelopathy, soil microbial communities interfere with activity of plants secondary metabolites, so studies based on bioassays require the incorporation of microbes, as it can decrease the activity and concentration of chemicals decomposition of compound after entry in soil. The effect of Calotropis procera plant parts extract on a a cyanophycean alga Chroococcus minutus was studied. The leaves extract showed the significant increase in blue green algal cells growth where as the flower, stem and root extract affected the growth of $C$. minutus moderately. However the latex extract was found to be toxic.
\end{abstract}

Keywords: allelopathy, secondary metabolites, cyanophycean alga.

\section{INTRODUCTION:}

Cyanobacteria, or blue green algae, are widely distributed all over the world, in a great variety of ecosystems. They are especially interesting as they contribute to soil fertility in agroecosystems (Roger and Watnabe, 1986). Chroococcus. minutus is used as remedy for the biotransformation of pollutants, including nutrients (Sivasubramanian et al., 2009). Calotropis procera (Ait) member of family Asclepediaceae, is an abundantly growing, laticiferous medicinal weed plant of tropical regions that contains ample amount of secondary metabolites. Thus keeping in this view allelopathic effect of C. procera was assessed on C. minutes, a soil habitant blue green algae.

\section{METHOD AND MATERIAL:}

\section{Preparation of algal inoculums for assessment:-}

For the preparation of algal inoculums, $500 \mathrm{ml}$ of culture was taken from the one month old unialgal liquid culture of $C$. minutus, and subsequently filtered with help of Watman Filter paper 40 to get a lump of alga to which, $100 \mathrm{ml}$ of sterile distilled water was added and swirled in vortex cyclomixer to get the uniform inoculums. This homogenous culture was used as starter culture for the experiment.

\section{Preparation of Calotropis plant parts extract:-}

$5 \mathrm{gm}$ of plant material (fresh material was finely chopped), to make fresh extract (latex in $\mathrm{v} / \mathrm{v}(\mathrm{ml})$ and dried material which was ground to powder added to $100 \mathrm{ml}$ of distilled water and kept overnight in rotatory shaker filtered with wattman filter paper. This was used as $100 \%$ concentrate. These extracts were further diluted with distilled water to make $50 \%, 25 \%, 10 \%, 5 \%$ and $1 \%$ concentration. Distilled water was used as control.

Evaluation of effect of Calotropis plant part extract (dried and fresh) on Alga:-

Assessment procedure: - $5 \mathrm{ml}$ of starter culture was poured in test tubes to which $500 \mu 1$ dried/fresh extract of Calotropis plant parts was added in different concentration separately in triplicates and distilled water was used as control.

a) Initial assessment was through visual observation by the color intensity of extract treated cultures.

b) Effect was confirmed by counting the algal cells in Hemocytometer.

\section{Counting the cells in Hemocytometer:-}

Test tubes of liquid culture were swirled in vortex cyclomixer for 2 minutes, to prepare the homogenous algal cell suspension. $0.5 \mathrm{ml}$ Lugol's solution $(\mathrm{KI} 3+\mathrm{CH} 3 \mathrm{COOH})$ was added the cell 
suspension to kill and immobilize algal cells. Then $10 \mu 1$ of this suspension was carefully loaded in grid and the number of cells was counted. The cell density in $1 \mathrm{ml}$ cell suspension was calculated from the following calculation (Stein, 1973)-

Density of cells $/ \mathrm{ml}=$ Average number of cells counted $\times$ Dilution factor $\times 10^{4}$

Statistical Analysis: All the data collected was analyzed using Analysis of Variance with Duncan's Multiple Range Test (Gomez et al, 1984).

\section{RESULTS AND DISCUSSION}

The effect of Calotropis on Chroococcus was observed by counting the number of cells in Hemocytometer.

The total number of cells $311437 / \mathrm{ml}$ in fresh leaves extract showed significant $(1 \%)$ increase. The total number of cells was found to be reduced in rest all the plant part extract treated on blue green algal culture at $1 \%$ level of significance. Plants producing secondary metabolites with a significant biological activity are subjected to cause stimulatory/inhibitory effect on plants and microbes in its vicinity. (Phillinger et.al 1995; Park et al 2006). Calotropis contains a number of biologically active components which are toxic to microorganism. This justifies the inhibitory effect of Calotropis on the alga with respect to both fresh and dried plant parts like flower, stem, root and latex. The inhibitory effect of latex might be due to the presence of toxic glycosides in latex. From the elemental analysis of Calotropis (Verma, 2014) leaves are found to be rich source of nutrition which might be the possible cause for enhancement in growth of alga (Sofowara, 1993). This is seen in the stimulatory growth of Chroococcus on being treated with fresh and dried leaf extracts Of Calotropis. Gerhenzon and Dudareva (2007) suggested that triterpenes are the most common group of secondary compounds which can stimulate or inhibit the growth of associated organism. In context to this Callaway and Aschehong (2000); Ehlers and Thompson (2004) suggested that the microbial community can potentially interact with allelochemicals and may degrade it.

\section{CONCLUSION:}

The fresh leaves of Calotropis procera can be used as an additive to soil, to enhance the growth of microalgal components and Chroococcus minutus not only assuages the also toxicity Secondary metabolites present in rhizosphere, but also improves the soil structure.

\section{REFERANCE :}

Callaway, R.M. \& Ridenour, W.M. (2000) Novel weapons: invasive success and the evolution of increased competitive ability. Frontiers in Ecology and the Environment 2: 436-443.

Ehlers BK1, Thompson J.(2004) Do co-occurring plant species adapt to one another? The response of Bromus erectus to the presence of different Thymus vulgaris chemotypes. Pubmed Journals. 141(3)511-518

Gerhenzon, J. Dudewara (2007) The function of terpene natural product in the natural world. Natural chemical Biology 3: 408-414

Gomez, K. A. and Gomez, A. A.(1984). Statistical Procedures for Agricultural Research, 2nd Edn, John Willey and Sons, New York.

Park, M. J., Kim, S., Kim, H., Myang, G., Kang, Y. G. Yih, W. (2006) First successful culture of marine dinoflagellate Dinophysis accuminata. Aquatic Microbial Ecology. 45:101-106

Phillinger J.M., Gilmour I., and Ridge I., (1995)., Comparison of antialgal activity of brownrotted and white-rotted wood and in situ analysis of lignin., Journal of Chem. Ecol. 21:1113-1125.

Roger, P.A., Watnabe (1986) Technologies for utilizing biological nitrogen fixation in wetland rice. Freil. Res.9: 39-77

Sivasubramanian, V., Subramanian, V.V., Raghavan, B.G. and Ranjith kumar, R. (2009) Large scale phycoremediation of acidic effluent from alginate industry. Science Asia 35:220-226

Sofowora, A. 1993.Medicinal Plants and Traditional Medicine in Africa. Spectrum books limited, Ibadan, Nigeria. pp220-224.

Stein, J.R. (1973) Culture Methods and Growth Measurements. A Handbook of Phycological methods. Cambridge.

Verma M., Sharma,A., Naidu S., Bhandra A.K., Taneja V, (2014),. Curcumin prevents formation of polyglutamine Aggregates bu inhibiting, VPS 36, a compound of the ESCRTII Complex. PLoS One 7 (8): e42923. 
Table No. 10 : Effect of Calotropis plant parts on Chroococcus minutes

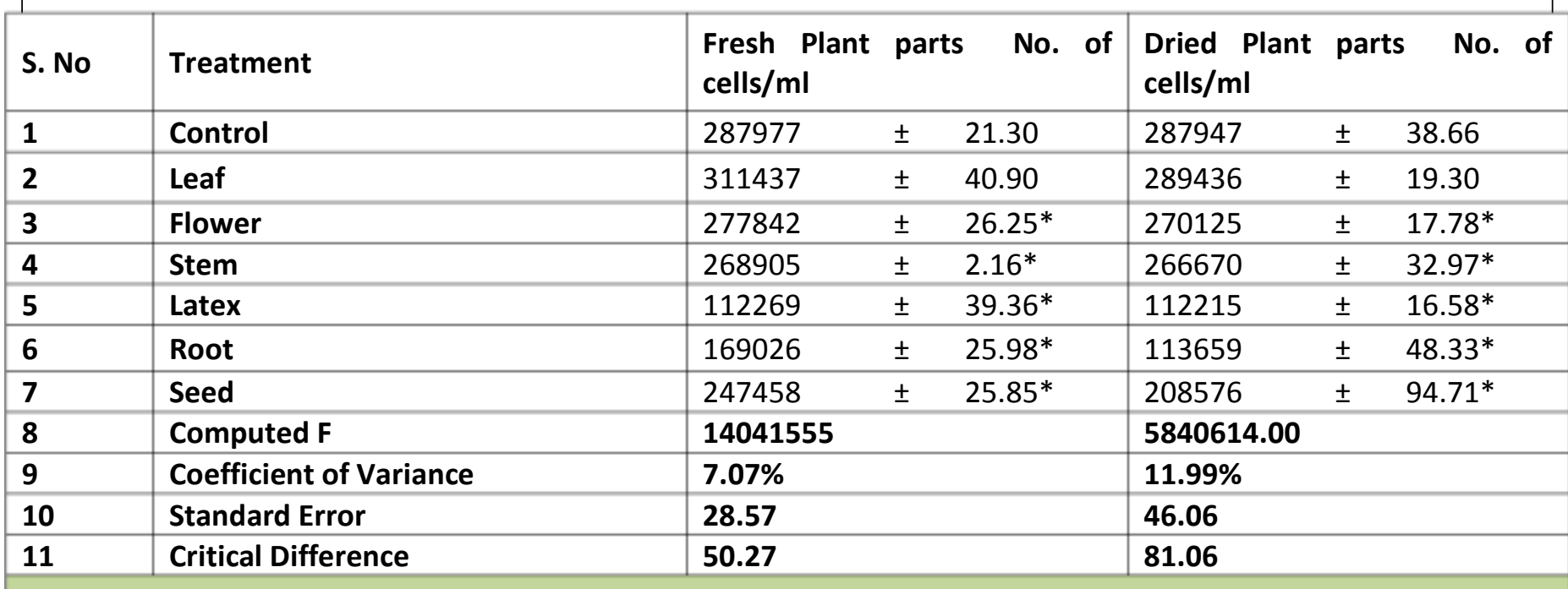

Note: TabularF (i) at $0.05=2.85$ and (ii) at $0.01=4.46$ and t-value at $5 \%=1.76$, $a^{*}=$ significant at $1 \%$ 